\title{
Two new species of philometrid nematodes (Philometridae), Barracudia notabilis n. sp. and Philometra consimilis n. sp., from the ovary of the hound needlefish Tylosurus crocodilus (Belonidae) off Florida, USA
}

\author{
F. MORAVEC ${ }^{1, *}$, M. D. BAKENHASTER ${ }^{2}$
}

\begin{abstract}
${ }^{1}$ Institute of Parasitology, Biology Centre of the Czech Academy of Sciences, Branišovská 31, 37005 České Budějovice, Czech Republic, "E-mail: moravec@paru.cas.cz; ${ }^{2}$ Fish and Wildlife Research Institute, Florida Fish and Wildlife Conservation Commission, 100 Eighth Avenue Southeast, St. Petersburg, Florida 33701, USA
\end{abstract}

Article info

Received February 2, 2021

Accepted March 3, 2021

\section{Summary}

Two new species of philometrid nematodes (Philometridae), Barracudia notabilis n. sp. and Philometra consimilis $\mathrm{n}$. sp., are described from males found in the ovary of the hound needlefish Tylosurus crocodilus (Péron et Lesueur) (Belonidae) from off the Atlantic coast of Florida, USA. Both species are described and illustrated based on light and scanning electron microscopical examinations. Barracudia notabilis $\mathrm{n}$. $\mathrm{sp}$., the first representative of this genus from fishes in the Atlantic Ocean, can be differentiated from other congeners by the body length of the male $(2.69 \mathrm{~mm})$, the length of the gubernaculum $(57 \mu \mathrm{m})$ and spicules $(81 \mu \mathrm{m})$, and by the shape of the gubernaculum. Philometra consimilis $\mathrm{n}$. $\mathrm{sp}$. differs from all congeners mainly in the unique structure of the distal tip of the gubernaculum (bearing two smooth dorsal barbs) and the species is also characterized by the length of spicules $(111 \mu \mathrm{m})$ and the length of the gubernaculum $(84 \mu \mathrm{m})$. Further studies are needed to discover and describe so far unknown gravid females of Barracudia spp.

Keywords: parasite; Dracunculoidea; marine fish; Atlantic Ocean; North America
Introduction

Nematodes of the dracunculoid family Philometridae Baylis et Daubney, 1926 represent a large group of important fish parasites many species of which occur in marine fishes. The taxonomy of these histozoic parasites is complicated by their marked sexual dimorphism in which females are highly modified and considerably larger than the males. In contrast to conspicuous, large-sized and often red-coloured philometrid females, conspecific minute males pass usually unnoticed during routine examinations of fish and that is why the males of many philometrids remain unknown (Moravec, 2006).

Needlefishes (Beloniformes: Belonidae) have frequently been reported as hosts of philometrid nematodes. They are small to medium sized, torpedo-shaped, predominantly piscivorous, sur- face-oriented species prized in some areas as food fish or bait for large offshore predators like marlin (Istiophoridae) (Collete, 2016). The common name for the family is derived from members' needle-like toothy beaks. Moravec et al. (2021) recently provided a review of belonid-infecting philometrids globally, and described as new two philometrid species infecting the Atlantic needlefish Strongylura marina (Walbaum) and the redfin needlefish Strongylura notata (Poey) from estuarine waters along the Gulf of Mexico coast of Florida, USA. The field collections of Moravec et al. (2021) also yielded specimens of hound needlefish Tylosurus crocodilus (Péron et Lesueur) that were hosts to the philometrid species described herein. Tylosurus crocodilus, known locally as houndfish (Page et al., 2013), is primarily considered a coastal species but is also found offshore (Collete, 2016) through much of the tropical and temperate oceans of the world (Froese \& Pauly, 2021). It is

\footnotetext{
* - corresponding author
} 


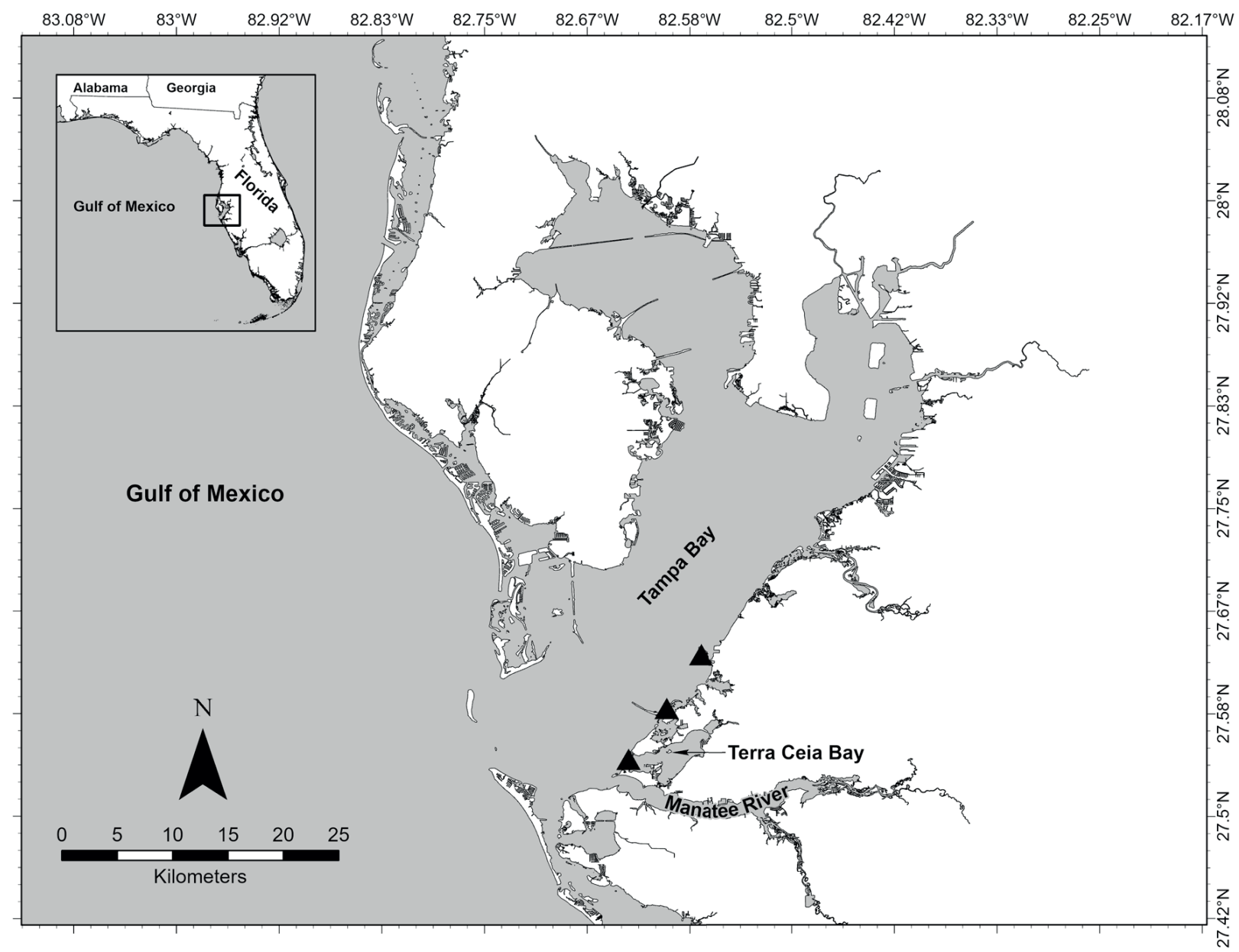

Fig 1. Map of Tampa Bay, Florida, USA, showing three collection localities for hosts, Tylosurus crocodilus, found to be infected by Philometra consimilis n. sp. or both that species and Barracudia notabilis $\mathrm{n} . \mathrm{sp}$.

large among belonids, reaching lengths in excess of $1 \mathrm{~m}$, and it is notable for being traumatogenic. It has caused serious, even fatal, puncture wounds in humans owing to its shape and habit of leaping horizontally over the water surface at high speeds (Manh et al., 2020).

Regarding previous records of philometrids from $T$. crocodiIus, Nikolaeva and Parukhin (1968) recorded gravid females of Philometra sp. from the swimbladder of this host species (reported as Strongylura raphidoma) in the Gulf of Mexico, Moravec and Ali (2005) the females of Philometra tylosuri Moravec et Ali, 2005 from the subcutaneous tissue and musculature of $T$. crocodilus in the Persian Gulf (off Iraq), Moravec and Justine (2009) the males of Philometra dentigubernaculata Moravec et Justine, 2009 from the oculo-orbits of $T$. crocodilus from off New Caledonia, and Moravec et al. (2012) the gravid female of Philometroides indonensiensis Moravec, Walter et Yuniar, 2012 from the musculature of T. crocodilus from off Indonesia. Apparently, also the females reported as Philometra sp. from the musculature of this host species in the Philippines and Indonesia by Petersen et al. (1993) and Jacob and
Palm (2006), respectively, belonged to this species (see Moravec et al., 2021); Philometra sp. was also listed as a parasite of $T$. crocodilus in the Persian Gulf off Al Qatif, Saudi Arabia by Mohamed et al. (2010).

Records of philometrids from other congeneric hosts include that of Linton (1907) reporting female specimens of Philometra sp. (misidentified as Ichthyonema [ $=$ Philometra] globiceps - see Moravec \& Tedesco, 2015) from the musculature of Tylosurus acutus (Lacepède) from Bermuda and those of Moravec and Rohde (1992) reporting females of Philometra kohnae Moravec et Rohde, 1992 and P. Iomi Moravec et Rohde, 1992 from the subcutaneous tissues of Tylosurus gavialoides (Castelnau) from off Australia.

\section{Materials and Methods}

Fish were collected in lower Tampa Bay (Fig. 1) during routine fish population monitoring conducted by the Florida Fish and Wildlife Conservation Commision' Fish and Wildlife Research Institute (FWRI). Haul seines, $183 \mathrm{~m}$ in length, were deployed along the 

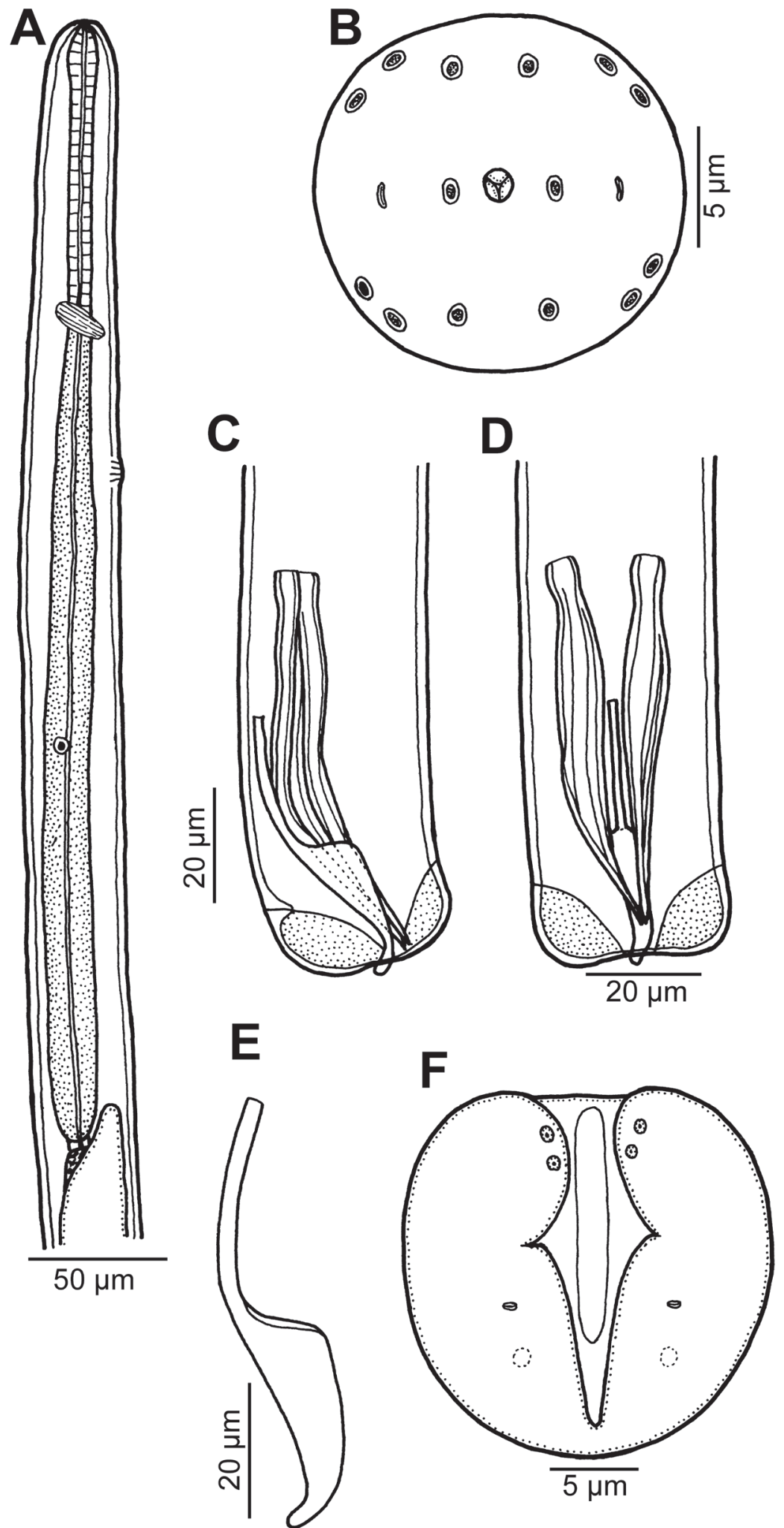

Fig. 2. Barracudia notabilis n. sp. from T. crocodilus, male. A - anterior end of body, lateral view; B - cephalic end, apical view; C, D - caudal end, lateral and ventral views, respectively; $\mathrm{E}$ - gubernaculum, lateral view; F - caudal end, apical view 
shoreline from net wells of mullet skiffs (see Wessel \& Winner, 2003). Captured fish were bagged in plastic and immediately packed in ice until crews returned at the end of field days to FWRI Headquarters in St. Petersburg Florida for further processing (time on ice $<12$ hrs).

In the laboratory, fish were measured for standard length, and examined for parasites. Gonad-infecting philometrids were surveyed and fixed for morphological study in $5 \%$ formalin by methods of Moravec et al. (2021). So fixed, specimens were shipped by commercial courier to the Institute of Parasitology, Biology Centre of the Czech Academy of Sciences, České Budějovice, Czech Republic for microscopic evaluation and description.

For light microscopical examination, the nematodes were cleared by use of glycerine. Drawings were made with the aid of a Zeiss drawing attachment. Specimens used for scanning electron microscopy (SEM) were postfixed in $1 \%$ osmium tetroxide (in phosphate buffer), dehydrated through a graded acetone series, critical-point-dried and sputter-coated with gold; they were examined with a JEOL JSM-7401F scanning electron microscope at an accelerating voltage of $4 \mathrm{kV}$ (GB low mode). All measurements are in micrometres unless otherwise indicated. The fish nomenclature adopted follows FishBase (Froese \& Pauly, 2021).

\section{Ethical Approval and/or Informed Consent}

All applicable institutional, national and international guidelines for the care and use of animals were followed.

\section{Results}

Family Philometridae Baylis et Daubney, 1926

\section{Barracudia notabilis $\mathrm{n} . \mathbf{s p}$.}

(Figs. 2-4)

Description: Male (1 specimen, holotype): Body filiform, whitish, $2.69 \mathrm{~mm}$ long, maximum width 36 ; anterior part of body somewhat narrowed towards cephalic extremity (Fig. 2A). Maximum width/ body length ratio 1:18. Cuticle smooth. Cephalic end rounded, 27 wide. Oral aperture small, circular. Fourteen minute cephalic papillae arranged in 2 circles present: external circle formed by 4 submedian pairs of papillae; internal circle by 4 submedian and 2 lateral papillae. Small lateral amphids just posterior to lateral papillae of internal circle (Figs. 2B, 3A,B). Oesophagus 432 long, comprising $16 \%$ of body length, with inflation at anterior end measuring $27 \times$ 12; posterior part of muscular oesophagus overlapped by well-developed oesophageal gland with large cell nucleus; maximum width of gland 18 (Fig. 2A). Small ventriculus present, its length 6 , width 9 . Nerve ring and oesophageal nucleus 96 and 267 from anterior extremity, respectively (Fig. 2A). Excretory pore 162 from anterior end. Testis extending anteriorly approximately to level of oesophago-intestinal junction, overlapping posterior portion of oe- sophagus (Fig. 2A). Posterior end of body blunt, 39 wide, provided with broad U-shaped mound situated laterally and dorsally to cloacal opening (Figs. 2F, 3C,D). At least 2 adanal pairs of very flat, hardly visible caudal papillae present between ventral ends of cloacal aperture and caudal mound (Figs. 2F, 3C). Pair of small phasmids present dorsoventrally on caudal mound (Figs. $2 F, 3 C, D)$. Caudal mound with pair of minute circular depression (Figs. 2F, $3 C, D)$. Cloacal aperture oval, markedly dorsoventrally elongated (Figs. 2F, 3C). Spicules sickle-shaped in lateral view, equally long, with somewhat expanded proximal and sharply pointed, ventrally oriented distal tips (Fig. 2C,D, 4); in ventral view, middle portion of spicules markedly broad, 9 wide (Fig. 2D); length of spicules 101, representing $3 \%$ of body length. Gubernaculum 57 long, with narrow, weakly-sclerotized tubular proximal portion; distal portion of gubernaculum broad, heavily sclerotized, wedge-shaped in lateral view, its distal tip rounded, dorsally curved (Fig. 2C,E, 4). Length ratio of gubernaculum and spicules 1:1.42. Spicules and gubernaculum well sclerotized, brownish (Fig. 4).

Female: Not known.

\section{Taxonomic summary}

Type host: Hound needlefish Tylosurus crocodilus (Péron et Lesueur) (Belonidae, Beloniformes); 503 mm (SL).

Site of infection: Ovary.

Type locality: Tampa Bay, Florida, Rattlesnake Key at mouth of Terra Ceia Bay (27.5474, -82.633250), USA (collected 7 November 2017).

Prevalence and intensity: 1 fish infected/5 fish examined); 1 nematode.

Type specimen: Male holotype (mounted on SEM stub) in the Helminthological Collection of the Institute of Parasitology, BC CAS, České Budějovice, Czech Republic (Cat. No. N-1229).

Etymology: The specific name notabilis (= remarkable, notable) is a Latin adjective that refers to the unusual shape of the gubernaculum.

\section{Remarks}

In having ventrally curved, sickle-shaped spicules, the distal tip of the gubernaculum oriented dorsally and the cloacal aperture markedly dorsoventrally elongate, this nematode belongs to the philometrid genus Barracudia Moravec et Shamsi, 2017. To date, only two species of Barracudia are known, both parasitizing barracudas (Sphyraenidae): B. australiensis Moravec et Shamsi, 2017 from the gall-bladder of Sphyraena obtusata Cuvier off Australia and B. philippinensis (Quiazon et Yoshinaga, 2013) from the ovary of Sphyraena forsteri Cuvier off the Philippines (Quiazon \& Yoshinaga, 2013; Moravec \& Shamsi, 2017).

Barracudia notabilis $\mathrm{n}$. $\mathrm{sp}$. differs from two other congeners mainly in the shape and structure of the gubernaculum (proximal portion of the gubernaculum narrow, almost straight, posterior portion conspicuously broad, wedge-shaped in lateral view, with a narrowed, 

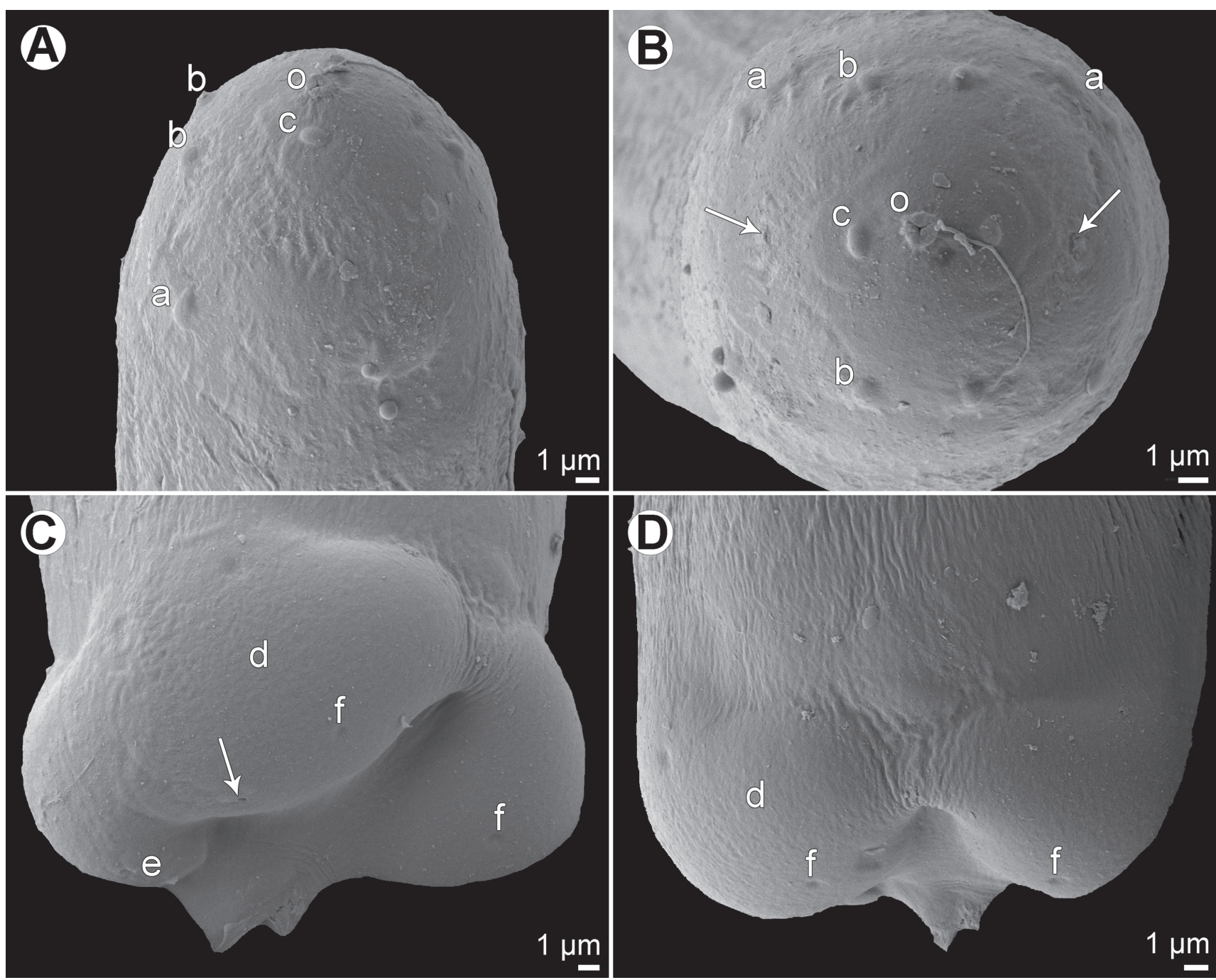

Fig. 3. Barracudia notabilis n. sp. from T. crocodilus, scanning electron micrographs of male. A, B - cephalic end, lateral and apical views, respectively (arrows indicate amphids); C, D - caudal end, sublateral and dorsal views, respectively (arrow indicates phasmid).

Abbreviations: a - pair of cephalic papillae of outer circle; $b$ - submedian cephalic papilla of inner circle; $c$ - lateral cephalic papilla of inner circle; $d$ - caudal mound; $\mathrm{e}-$ two adanal papillae; $f$ - cuticular depression; 0 - oral aperture

smooth, dorsally curved distal tip vs. proximal end of the gubernaculum narrowed, strongly curved dorsally, distal tip smooth, laterally expanded, with a minute terminal digital projection in $B$. australiensis or proximal end of the gubernaculum rather broad, slightly dorsally bent, distal tip with a reflected dorsal barb and lamellate structure in $B$. philippinensis). It also differs in the male body length $(2.69 \mathrm{~mm}$ vs. $5.02 \mathrm{~mm}$ or $3.05-3.78 \mathrm{~mm})$, the length of the gubernaculum and spicules (gubernaculum $57 \mu \mathrm{m}$ vs. 63 $\mu \mathrm{m}$ or $90-103 \mu \mathrm{m}$; spicules $81 \mu \mathrm{m}$ vs. $108 \mu \mathrm{m}$ or $82-88 \mu \mathrm{m}$ ) and in the gubernaculum/spicules length ratio (1:1.42 vs. 1:1.71 or 1:1.06-1.24). The new species also differs in the family and order of fish hosts (Belontidae, Belontiformes vs Sphyraenidae, Perciformes) and in the geographical region (Atlantic Ocean vs
South Pacific Ocean or South China Sea).

Worth noting, however, is that three sphyraenids occur sympatrically with $T$. crocodilus in the Gulf of Mexico, Sphyraena barracuda (Edwards), S. borealis DeKay and S. guachancho Cuvier (Russell, 2002); these likely prey on the same potential intermediate host species, leaving open the intriguing possibility that members of Barracudia, including the new species, are typically parasites of sphyraenids and that $T$. crocodilus is a paradefinitive host. Reproducing females of Barracudia notabilis must be found to test this hypothesis, and special care would be warrented in identification or first description of any philometrids that might be collected in the future from Western Atlantic Sphyraena spp. 


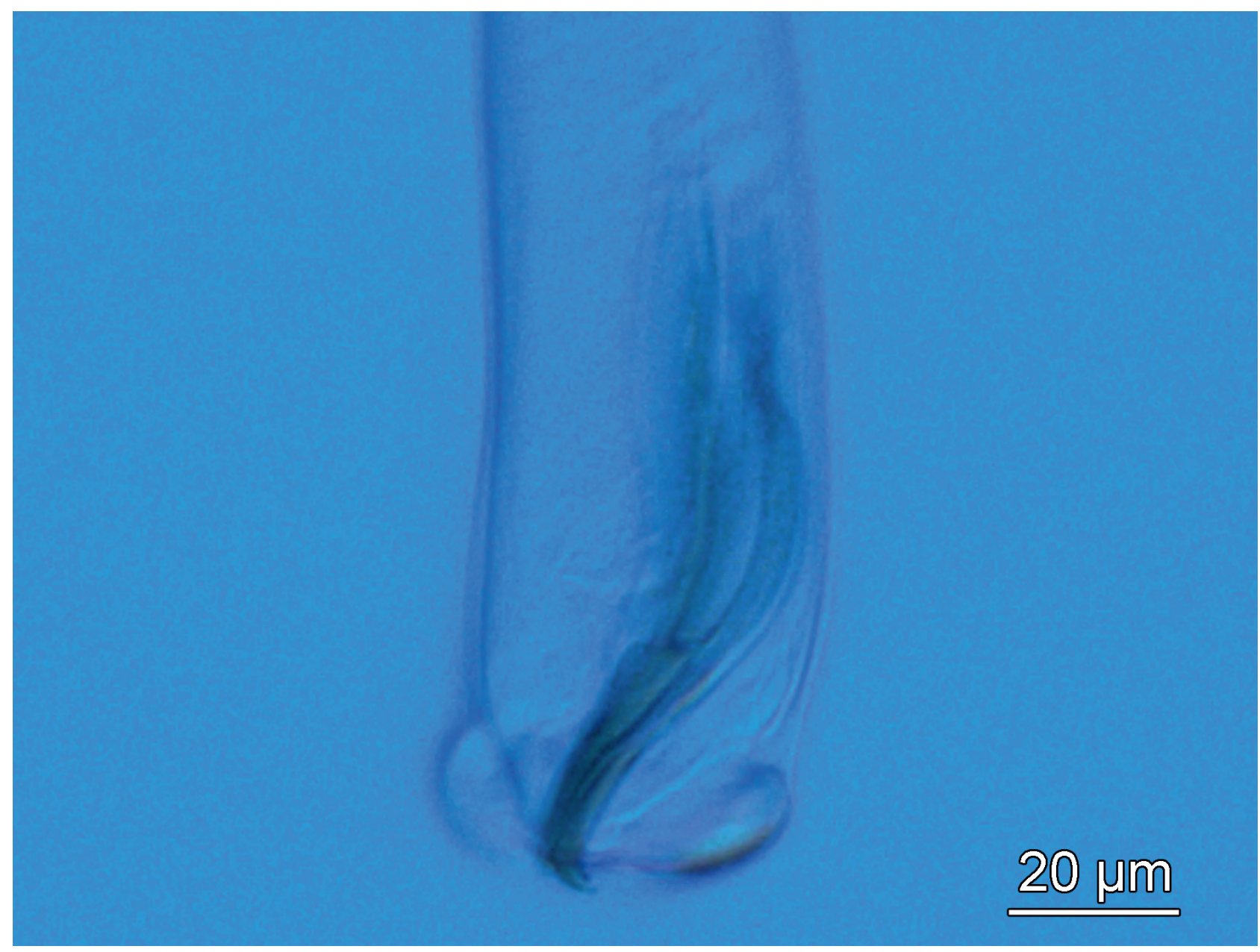

Fig. 4. Caudal end of Barracudia notabilis n. sp., lateral view

\section{Philometra consimilis $\mathbf{n}$. sp.}

(Figs. 5, 6)

Description: Male (6 specimens; measurements of holotype in parentheses): Body filiform, whitish, $2.19-3.81$ (3.44) mm long, maximum width at middle of body $33-48$ (48); anterior part of body tapering to anterior extremity, with slightly outlined constriction just posterior to cephalic end (Fig. 5A). Maximum width/body length ratio 1:66 - 94 (1:72). Cuticle smooth. Cephalic end rounded, 21 - 33 (33) wide, width at cephalic constriction 18 - 30 (30). Small oral aperture surrounded by 14 cephalic papillae arranged in 2 circles and pair of amphids, as in males of all other philometrid species (cephalic ends used for SEM proved to be very damaged and unsuitable for illustrations). Oesophagus $282-441$ (441) long, comprising $7-13$ (13) \% of body length, with slight inflation at anterior end measuring $21-36 \times 12-21(36 \times 21)$; posterior part of muscular oesophagus overlapped by well-developed oesophageal gland with large cell nucleus; maximum width of gland $15-21$ (21) (Fig. 4A). Ventriculus small, 6 - 15 (15) long,
9 - 18 (18) wide. Nerve ring and oesophageal nucleus $126-198$ (198) and $201-327$ (327), respectively, from anterior extremity. Excretory pore $171-216$ (216) from anterior end. Posterior end of body blunt, 30 - 45 (45) wide, with broad caudal mound formed by 2 lateral reniform portions well separated dorsally (Figs. 5D, 6A,B). Four pairs of small adanal papillae present in space between caudal mound and cloacal aperture: 2 pairs of small, markedly elevated papillae situated closely to cloacal aperture and 2 pairs of very flat, hardly visible papillae located externally to them; pair of small phasmids present dorsoventrally on caudal mound (Figs. 5D, $6 \mathrm{~B}-\mathrm{F})$. Each portion of caudal mound with 1 subdorsal, minute circular depression (Figs. 5D, 6B). Spicules needle-like, equally or nearly equally long, with somewhat expanded proximal and sharply pointed distal tips (Fig. 5B,C); length of spicules 105-117 (117), maximum width 6 (6); length ratio of spicules 1:1.00-1.03 (1:1.00); spicules representing $2.9-4.8$ (3.4) \% of body length. Gubernaculum narrow, 78 - 90 (90) long, with anterior portion somewhat dorsally bent; length of anterior bent part $45-57$ (48), comprising $53-63(53) \%$ of entire gubernaculum length (Fig. 5B,C,E - G). 

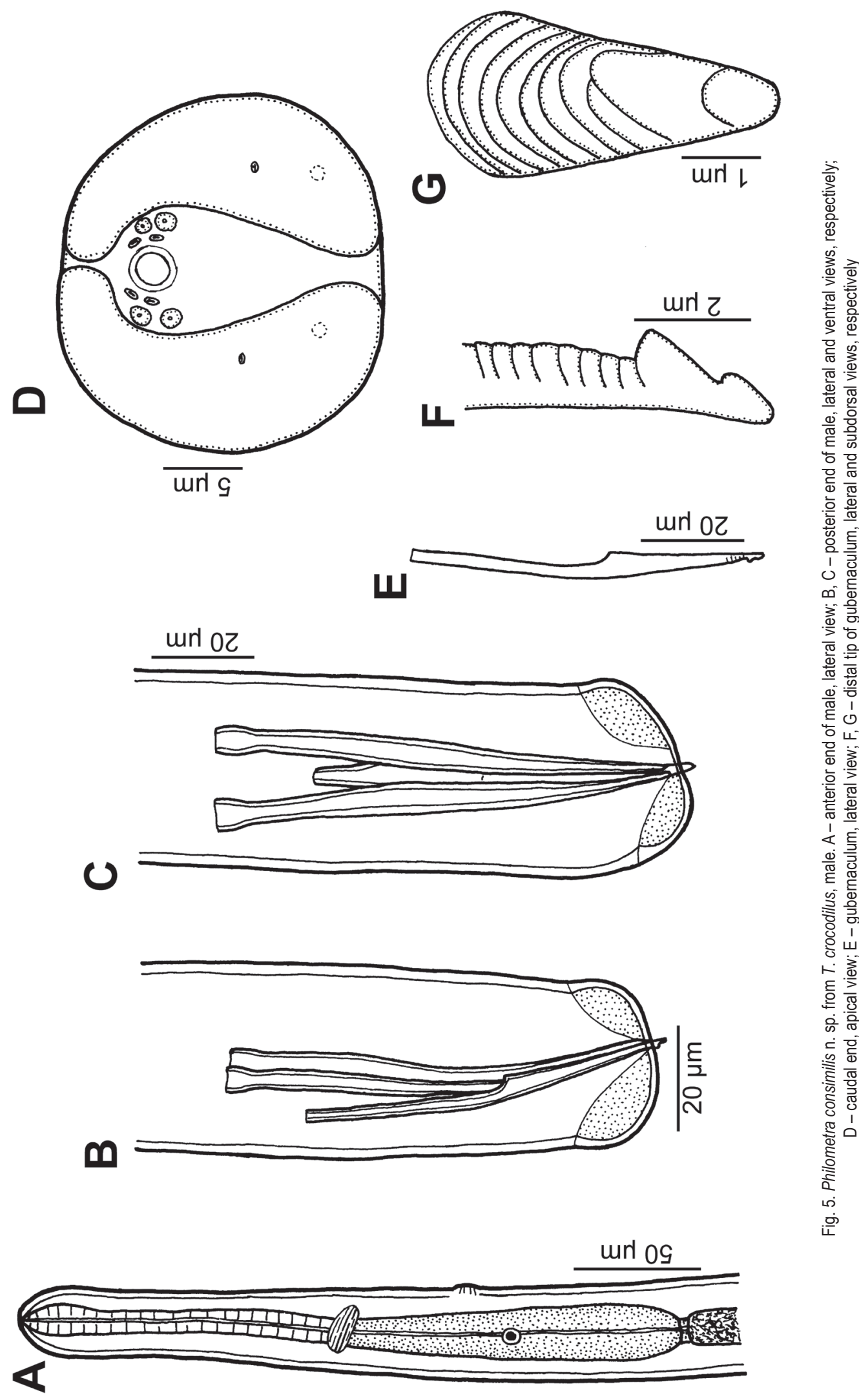
In lateral view, distal tip of gubernaculum with 2 smooth, reflexed dorsal barbs (1 large and 1, more distal barb small) and with several transverse, dorsally uninterrupted lamellae in region anterior to barbs; proper extremity of gubernaculum posterior to barbs rounded (Figs. 5F,G, 6C - F). Length ratio of gubernaculum and spicules 1:1.23 - 1.35 (1:1.30). Spicules and gubernaculum well sclerotized, yellowish, anterior part of gubernaculum and proximal ends of spicules colourless.

Female: Not known.

\section{Taxonomic summary}

Type host: Hound needlefish Tylosurus crocodilus (Péron et Lesueur) (Belonidae, Beloniformes); $503 \mathrm{~mm}$ (SL).

Site of infection: Ovary.

Type locality: Tampa Bay (27.632516, -82.574166), Gulf of Mexico, USA (collected 9 December 2019).

Other locality: Tampa Bay (27.588783, -82.602266; 27.5474, -82.633250), Gulf of Mexico, USA (collected 15 September and 7 November 2017).

Prevalence and intensity: 4 fish infected/5 fish examined; 1 - 4 nematodes per fish.

Type specimens: Holotype and 2 paratypes in the Smithsonian National Museum of Natural History, Washington, USA (Cat. Nos. USNM 1640967 and USNM 1640968, respectively); 2 paratypes in the Helminthological Collection of the Institute of Parasitology, BC CAS, České Budějovice, Czech Republic (Cat. No. N-1230). Etymology: The specific name consimilis (= much like) is the Latin adjective relating to the fact that this species is very similar to Philometra aequispiculata Moravec, Bakenhaster, Seyoum et Tringali, 2021, a recently described gonad-infecting species parasitizing Strongylura spp. in the Gulf of Mexico (Moravec et al., 2021).

\section{Remarks}

The males of this new species are morphologically and biometrically very similar to those of $P$. aequispiculata, but differ in the longer gubernaculum (78 - $90 \mu \mathrm{m}$ vs. 60 - $69 \mu \mathrm{m})$ and a differnt length ratio of the gubernaculum and spicules (1:1.23 - 1.35 vs. $1: 1.50-1.67)$. However, the main difference is in the structure of the distal gubernaculum tip: whereas that of $P$. consimilis $n . s p$. possesses two smooth dorsal barbs, the larger barb of $P$. aequispiculata bears three distinct lateral transverse grooves and there are two uninterrupted lamellar structures posterior to it. Moreover, the fish hosts of these species belong to different genera (Tylosurus Cocco vs Strongylura van Hasselt).

One male of $P$. consimilis $\mathrm{n}$. $\mathrm{sp}$. was collected from the ovary of the same specimen of $T$. crocodilus, in which also a single specimen of Barracudia notablilis n. sp. was found.

\section{Discussion}

While the morphology of $P$. consimilis n. sp. is typical of gonad-in- fecting species of Philometra Costa, 1845, the finding of a representative of another philometrid genus, $B$. notabilis $n$. sp., in the ovary of $T$. crocodilus is remarkable, especially in a co-infection with $P$. consimilis. It should be noted that all hitherto described species of Barracudia are known only by males and juvenile females. Whereas the specimens of $B$. philippinensis and $B$. notabilis $\mathrm{n}$. $\mathrm{sp}$. were found in the hosts' ovary, those of $B$. australiensis were recovered from the host's gall bladder.

This indicates a possibility that the location of large, subgravid and gravid females of Barracudia spp. in the host is other than fish gonads. In fact, $T$. crocodilus is reported as the host of $P$. tylosuri, a species described from a single nongravid female from the fish musculature in the Persian Gulf, or of Philometra sp. based on females found in the musculature or the swimbladder from off the Philippines and Indonesia and in the Gulf of Mexico (see above). Since the males of these nematodes remain unknown and the genus Barracudia was based solely on male morphology, it cannot be excluded that at least some of these philometrid females might belong to Barracudia. Therefore, new studies in this respect are needed to elucidate this problem.

The present description of $P$. consimilis $n$. sp. demonstrates again the importance of detailed studies of male morphology for the distinction between similar species of philometrids. It is believed that subsequent studies on the fauna of philometrids parasitizing fishes in the Gulf of Mexico will enable the discovery and description of the hitherto unknown gravid females of $P$. consimilis $\mathrm{n}$. $\mathrm{sp}$.

\section{Acknowledgements}

We thank many colleagues at the Fish and Wildlife Research Institute, particularly the numerous biologists of the Fisheries Independent Monitoring Program (FIM) whose labors and attention to detail yeilded high quality fish specimens for parasitological evaluation. Greg Onorato (FIM) supported our specimen requests and allocated resources. Deb Leffler, Tim McDonald (both FIM), and Theresa Cody of the Fish and Wildlife Health group (FWH) also directed critical resources in support of our work. Adam Richardson and Eli Bastian (both FWH) provided laboratory and data processing support. Figure 1 was created by Latosha Thompson of the Center for Spatial Analysis. Thanks are also due to the Laboratory of Electron Microscopy, Institute of Parasitology, Biology Centre CAS, institution supported by the MEYS CR (LM2015062 Czech-Biolmaging) and ERDF (No. CZ.02.1.01/0.0/0.0/16_013/0 001775), for their support with obtaining scientific data presented in this paper, and to Blanka Škoríková of the same Institute for help with the illustrations. This study was partly supported by the institutional support of the Institute of Parasitology, BC AS CR (RVO: 60077344). Funding for Florida sampling and specimen processing was derived from State of Florida saltwater recreational fishing license revenues, and the US Department of the Interior (DOI) US Fish and Wildlife Service (USFWS) Wildlife and Sport Fish Restoration program (WSFR) [F17AF00793, F17AF00932, 


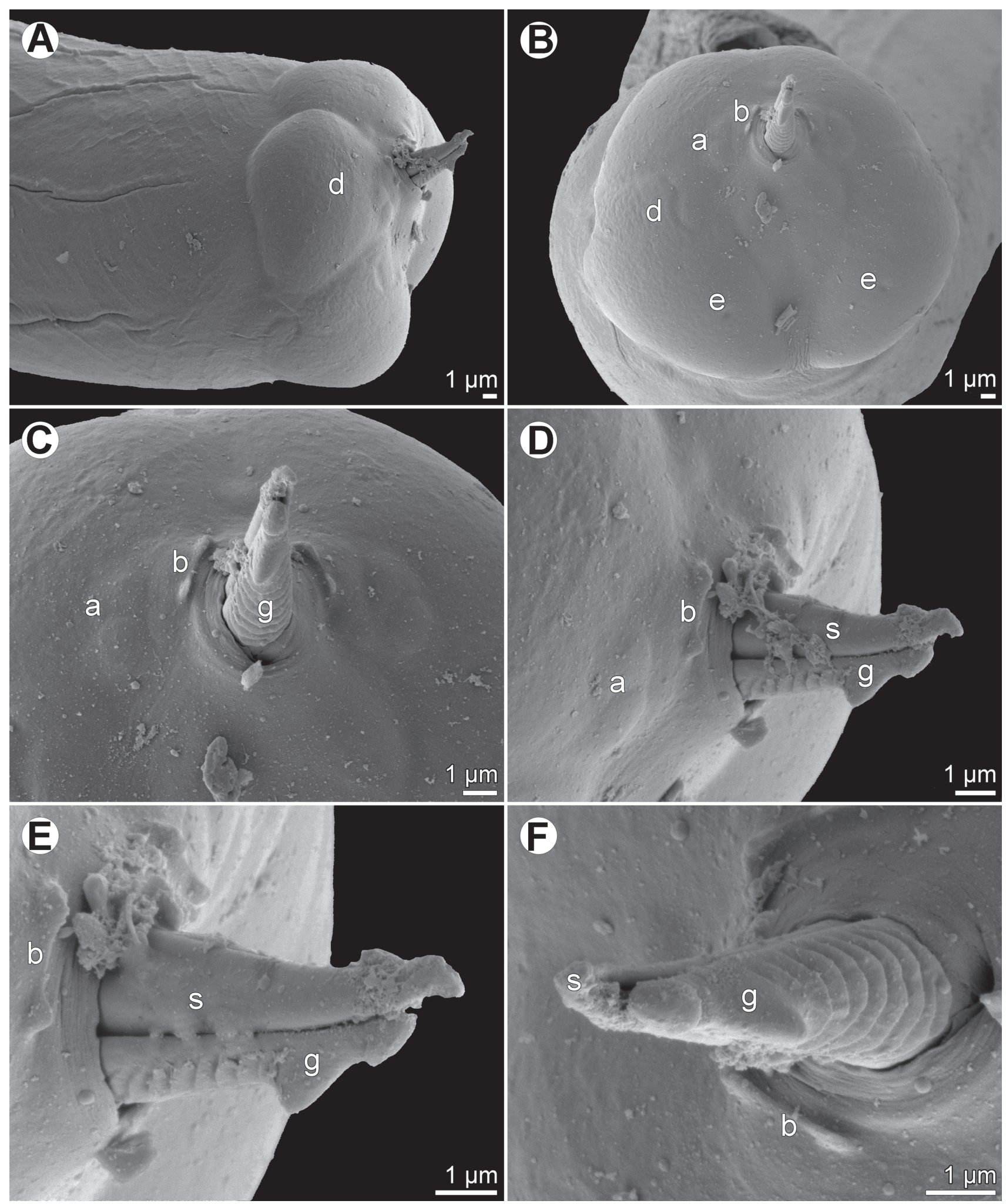

Fig. 6. Philometra consimilis sp. n. from T. crocodilus, scanning electron micrographs of male. A, B - caudal end, lateral and apical views, respectively; C, D - enlarged region of cloaca, apical and sublateral views, respectively; E, F - distal tip of gubernaculum, lateral and subdorsal views, respectively. Abbreviations: $a$ - two flat adanal papillae; $b$ - two elevated adanal papillae; $d$ - caudal mound; $e$ - cuticular depression; $g$ - gubernaculum; $s$ - spicule 
FR16AF00544]

Statements, conclusions, and recommendations are those of the authors and do not necessarily reflect the views or policies of the DOI, or the USFWS. Any opinions, views, statements, findings, conclusions, and recommendations expressed in this material are those of the authors; they do not necessarily reflect, and should not be interpreted as presenting, the opinions, views, or policies of the USFWS, WSFR, or the DOI. Nothing contained herein constitutes an endorsement in any respect by any part of the US Government or the State of Florida.

\section{Conflict of Interest}

The authors declare that they have no conflict of interest.

\section{References}

Collette, B.B. (2016): Belonidae, needlefishes. In: Carpenter, K.E. \& De Angelis, N. (Eds), The living marine resources of the Eastern Central Atlantic. Volume 3: Bony fishes part 1 (Elopiformes to Scorpaeniformes). FAO Species Identification Guide for Fishery Purposes. Food and Agriculture Organization of the United Nations, Rome, pp. $2118-2126$

JACOB, E., PALM, H.W. (2006): Parasites of commercially important fish species from the southern Java coast, Indonesia, including the distribution pattern of trypanorhynch cestodes. Verh. Ges. Ichthyol., 5: 163 - 191

Froese, R., Pauly, D. (Eds) (2020): FishBase. World Wide Web electronic publication. http://www.fishbase.org, version 01/2021

Linton, E. (1907): Notes on parasites of Bermuda fishes. Proc. U. S. Nat. Mus., 33: $85-126$

Manh, T.H., Szuflita, N.S., Thanh, V.V., Neal, C.J (2020): Penetrating spinal cord injury caused by a Needlefish: A case report and review of Needlefish trauma to the head and neck. Interdiscip. Neurosurg., 21: 100752. DOI: 10.1016/j.inat.2020.100752

Mohamed, A.H., Hassan, M.A., Mahmoud, M.A. (2010): Infestation of some marine fish species with red worm Philometra. Arab Gulf J. Sci. Res., 28: 137 - 146

Moravec, F. (2006): Dracunculoid and anguillicoloid nematodes parasitic in vertebrates. Academia, Prague, $634 \mathrm{pp}$.

Moravec, F., All, A.H. (2005): Two new species of Philometra (Nematoda: Philometridae) from needlefishes (Belonidae) in Iraq, with a key to Philometra spp. parasitic in the host's subcutaneous tissue, fins and musculature. Folia Parasitol., 52: 267 - 273. DOI: 10.14411/fp.2005.035

Moravec, F., Bakenhaster, M.D., Seyoum, S., Tringal, M.D. (2021): Morphological and genetic description of two new species of philometrid nematodes (Philometridae) parasitic in needlefishes (BeIonidae) from estuaries of Florida, USA. Folia Parasitol., 68: 008.
DOI: $10.14411 /$ fp. 2021.00

Moravec, F., JustinE, J.-L. (2009): New data on dracunculoid nematodes from fishes off New Caledonia, including four new species of Philometra (Philometridae) and Ichthyofilaria (Guyanemidae). Folia Parasitol., 56: 129 - 142. DOI: 10.14411/fp.2014.007

Moravec, F., Rohde, K. (1992): Three species of nematodes of the superfamily Dracunculoidea from Australian fishes. Acta Soc. Zool. Bohemoslov., 56: 187 - 195

Moravec, F., ShamsI, S. (2017): Barracudia australiensis n. g., n. sp. (Nematoda: Philometridae) from the obtuse barracuda Sphyraena obtusata Cuvier (Perciformes: Sphyraenidae) off eastern Australia. Syst. Parasitol., 94: 627 - 634. DOI: 10.1007/s11230017-9735-3

Moravec, F., Tedesco, P. (2015): Redescription of Philometra globiceps (Rudolphi, 1819) (Nematoda: Philometridae), the type species of Philometra Costa, 1845, including the first data obtained by SEM. Parasitol. Res., 114: 4413 - 4420. DOI: 10.1007/s00436015-4681-y

Moravec, F., Walter, T., Yuniar, A.T. (2012): Five new species of philometrid nematodes (Philometridae) from marine fishes off Java, Indonesia. Folia Parasitol., 59: 115 - 130. DOI: 10.14411/ fp.2012.017

Nikolaeva, V.M., ParUkhin, A.M. (1968): [Study of fish helminths in the Gulf of Mexico. In: Investigations of the Central-American seas (based on materials of the Soviet-Cuban marine expedition), Part II.] Naukova Dumka, Kiev, pp. 126 - 149 (In Russian with Spanish and English summaries).

Page, L.M., Espinosa-Pérez, H., Findley, L.T., Gilbert, C.R., Lea, R.N., Mandrak, N.E., Mayden, R.L., Nelson, J.S. (2013): Common and scientific names of fishes from the United States, Canada, and Mexico, 7th edition. Special Publication 34 of the American Fisheries Society, $243 \mathrm{pp}$.

Petersen, F., Palm, H., Möller, H., Cuzi, M.A. (1993): Flesh parasites of fish from central Philippine waters. Dis. Aquat. Org., 15: $81-86$

QuiaZon, K.M.A., YoshinaGa, T. (2013): Gonad-infecting philometrid Philometra philippinensis sp. nov. (Nematoda, Philometridae) from the bigeye barracuda Sphyraena forsteri Cuvier (Sphyraenidae) off Mariveles, Bataan Province, Philippine archipelago. Acta Parasitol., 58: 504 - 514. DOI: 10.2478/s11686-013-0165-3

RusselL, B.C. (2002): Belonidae, needlefishes. In: CARPENTER, K.E. \& De Angelis, N. (Eds) The living marine resources of the Eastern Central Atlantic. Volume 3: Bony fishes part 1 (Elopiformes to Scorpaeniformes). FAO Species Identification Guide for Fishery Purposes. Food and Agriculture Organization of the United Nations, Rome, pp. $2118-2126$

WESSEL, M.R., WINNER, B.L. (2003): Using a modified purse seine to collect and monitor estuarine fishes. Gulf Caribb. Res., 15: 61 $-71$ 